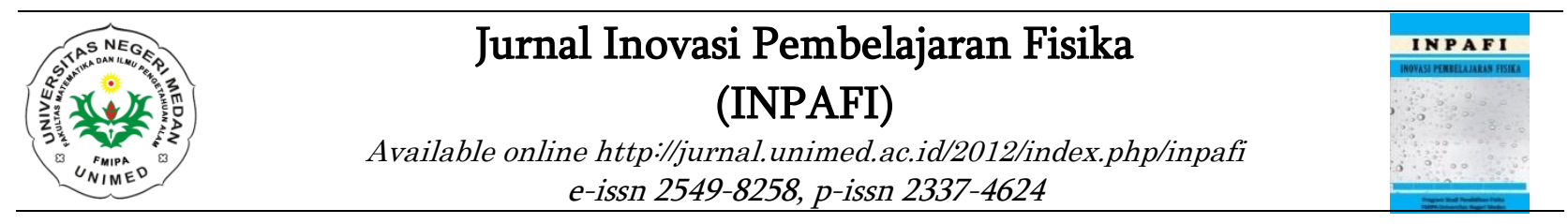

\title{
PENGARUH MODEL PROBLEM BASED LEARNING TERHADAP KEMAMPUAN PEMECAHAN MASALAH PADA MATERI SUHU DAN KALOR DI KELAS X SEMESTER II SMA NEGERI 5 MEDAN T.P. 2017/2018
}

\author{
Abu Bakar dan Maria Evlin Panjaitan \\ Jurusan Fisika FMIPA Universitas Negeri Medan \\ panjaitanmaria114@gmail.com, abubakar1409yahoo.co.id \\ Diterima: September 2018. Disetujui: Oktober 2018. Dipublikasikan: Nopember 2018
}

\begin{abstract}
ABSTRAK
Penelitian ini bertujuan untuk mengetahui pengaruh model pembelajaran berbasis masalah terhadap kemampuan pemecahan masalah siswa pada materi suhu dan kalor kelas X semester II SMA Negeri 5 Medan T.P. 2017/2018. Jenis penelitian ini adalah quasi experiment dengan desain penelitian yang digunakan adalah two group pretest-posttest design. Populasi penelitian adalah seluruh siswa kelas $\mathrm{X}$ seluruh siswa kelas X SMA Negeri 5 Medan sebanyak 7 kelas paralel. Pengambilan sampel dilakukan dengan teknik random sampling. Sampel penelitian terdiri dari 2 kelas, yang masingmasing berjumlah 33 siswa di SMA Negeri 5 Medan. Instrumen yang digunakan untuk mengetahui hasil belajar siswa adalah tes kemampuan pemecahan masalah berbentuk essay dengan jumlah 7 soal yang sudah divalidasi. Lembar penilaian sikap dan lembar keterampilan siswa. Hasil analisis data dengan uji t menunjukkan bahwa terdapat pengaruh yang signifikan dari model pembelajaran berbasis masalah terhadap kemampuan pemecahan masalah siswa pada materi pokok suhu dan kalor di kelas X semester II SMA Negeri 5 Medan T.P. 2017/2018.
\end{abstract}

Kata kunci : model problem based learning, suhu dan kalor, kemampuan pemecahan masalah.

\begin{abstract}
This study aimed to determine the effect of PBL model on problem solving ability of students in the subject matter of temperature and heat semester II class X SMA Negeri 5 Medan T.P. 2017/2018. This type of research is quasi experimental research design used is a two-group pretest-posttest design. Populasi research are all students of class X Semester II consisting of seven parallel classes. Sampling was done by random sampling. The study sampel consisted of two classes, each of which amounted to 33 students at SMA Negeri 5 Medan. The instrument used to determine student learning outcomes is problem solving test in essay test with a total of 7 validated questions. an assessment sheet of student learning affective assessmet and sheet of student learning psikomotorik. The results of data analysis using t-test showed that there is significant influence of problem based learning to problemsolving ability of students in the subject matter of temperature and heat in class X second half of SMA Negeri 5 Medan T.P. 2017/2018.
\end{abstract}

Keywords: problem based learning, temperature and heat, problem solving 
Abu Bakar dan Maria Evlin Panjaitan ; Pengaruh Model Problem Based Learning Terhadap Kemampuan Pemecahan Masalah Pada Materi Suhu Dan Kalor Di Kelas X Semester II Sma Negeri 5 Medan

T.P. $2017 / 2018$

\section{PENDAHULUAN}

Proses pendidikan pada intinya merupakan kegiatan pembelajaran di dalam kelas, karena itu peningkatan kualitas pendidikan dapat dilakukan melalui perbaikan proses pembelajaran untuk mencapai tujuan pembelajaran. Proses pembelajaran merupakan interaksi dua arah dari seorang guru dan peserta didik, dimana antara keduanya terjadi komunikasi (transfer) yang intens dan terarah menuju pada suatu target yang telah ditetapkan sebelumnya (Trianto, 2010). Baik atau buruknya proses pembelajaran tergantung bagaimana cara pengelolaan dalam kelas berlangsung. Guru sebagai pengelola kelas sebaiknya melahirkan interaksi belajar mengajar yang baik, untuk itu guru sebaiknya merencanakan kegiatan pengajarannya secara sistematis dengan memanfaatkan segala sesuatunya guna kepentingan pengajarannya. Guru juga dituntut harus profesional dalam melakukan tugastugasnya sebagai tenaga pengajar. Menurut Suyanto dan Jihad (2013) kemampuan profesional seorang guru pada hakikatnya adalah muara dari kemampuan dasar dan pemahaman yang mendalam tentang anak sebagai siswa, objek belajar dan situasi kondusif berlangsungnya kegiatan pembelajaran.

Kenyataannya, pelaksanaan kegiatan belajar mengajar di sekolah belum sesuai dengan harapan di atas. Masalah yang dihadapi adalah lemahnya proses pembelajaran. Hal ini disebabkan karena guru masih kurang maksimal dalam persiapannya. Anak kurang didorong untuk mengembangkan kemampuan berpikir tetapi guru aktif memberikan informasi dengan menjelaskan materi kemudian memberikan contoh soal sementara siswa pasif saat proses pembelajaran berlangsung.

Fisika merupakan bagian dari Ilmu Pengetahuan Alam (IPA) yang berisi kumpulan pengetahuan berupa fakta, konsep, prinsip, hukum, dan teori yang berhubungan dengan fenomena alam. Pembelajaran fisika dapat memberikan pengalaman langsung pada siswa sehingga menambah kemampuan dalam mengkonstruksi, memahami dan menerapkan pengetahuan yang telah dipelajari. Siswa akan terlatih menemukan sendiri berbagai konsep secara holistik, bermakna, outentik serta aplikatif untuk kepentingan pemecahan masalah. Fisika merupakan sekumpulan pengetahuan, cara berpikir, dan penyelidikan. Pembelajaran fisika seharusnya dapat menumbuhkan kemampuan berpikir siswa sebagai aspek penting dari kecakapan hidup. Salah satu bentuk kemampuan berpikir siswa yang harus dikembangkan adalah kemampuan pemecahan masalah. Hamalik (2003) mengatakan kemampuan pemecahan masalah adalah suatu proses mental dan intelektual dalam menemukan masalah dan memecahkan berdasarkan data dan informasi yang akurat, sehingga dapat diambil kesimpulan yang tepat dan cermat.

Cara siswa dalam memecahkan masalah menggambarkan penguasaan konsep siswa tersebut. Kenyataannya, siswa hanya ditekankan untuk menghafal teori dan rumus dan rumus saja agar mampu mengerjakan soal. Siswa dianggap telah menguasai konsep pembelajaran apabila telah mencapai standart nilai tertentu. Akibatnya siswa hanya menghafal konsep yang diberikan agar memperoleh nilai tinggi pada saat ujian. Proses pembelajaran yang demikian akan menghambat pengembangan kemampuan pemecahan masalah oleh siswa. Hal tersebut juga terjadi pada SMA Negeri 5 Medan, sehingga proses pembelajaran fisika yang di laksanakan di sekolah tersebut belum mengembangkan kemampuan pemecahan masalah oleh siswa secara optimal.

Berdasarkan observasi yang dilakukan peneliti di SMA Negeri 5 Medan, terdapat beberapa faktor yang menyebabkan rendahnya kemampuan pemecahan siswa. Cara guru menyajikan materi tidak menarik yaitu hanya dengan ceramah dan mengerjakan soal serta menurunkan rumus sampai papan tulis penuh dan siswa hanya menirukan cara guru dalam menjawab soal secara matematis tanpa mengerti konsep materi yang sebenarnya. Hal tersebut menyebabkan siswa menganggap bahwa fisika itu sulit dan membosankan sehingga siswa kurang terampil dalam kemampuan pemecahan masalah fisika. terdapat 19 siswa yang tidak tuntas dalam pembelajaran fisika dengan Kriteria Ketuntasan Minimal (KKM) yang ditetapkan 
adalah 75. Data tersebut dapat disimpulkan bahwa hanya $47 \%$ siswa yang tuntas dalam pembelajaran fisika. Hal ini dikarenakan siswa terbiasa mengerjakan soal-soal tes dalam bentuk persamaan matematis yang berprioritas pada proses penyelesaian soal tanpa menganalisis terlebih dahulu permasalahan yang diberikan.

Faktor lain yang menyebabkan rendahnya kemampuan pemecahan masalah siswa berdasarkan wawancara pada salah satu guru fisika adalah metode dan model pembelajaran yang digunakan guru kurang bervariasi. Pembelajaran fisika lebih dominan menggunakan metode ceramah, mencatat dan menghafal pelajaran, sehingga siswa menjadi pasif dan kurang terlibat dalam proses belajar mengajar. Kemudian kurangnya penggunaan media menjadi penyebab kurang aktifnya siswa dalam proses pembelajaran. Berdasarkan hasil observasi yang dilakukan peneliti mengenai sarana prasarana laboratorium di SMA Negeri 5 Medan sudah cukup lengkap tetapi belum digunakan secara maksimal karena keterbatasan waktu, Sehingga pembelajaran cenderung dilakukan di dalam kelas, hal ini membuat sebagian besar siswa kurang mampu menghubungkan antara apa yang dipelajari dengan bagaimana mengaplikasikannya pada situasi dalam kehidupan sehari-hari dan pada akhirnya menyebabkan kemampuan pemecahan masalah yang rendah.

Menanggapi permasalahan di atas perlu adanya model yang mengorientasikan pembelajaran pada masalah-masalah nyata yang dapat menciptakan keterlibatan siswa dalam proses belajar mengajar untuk menumbuhkan kemampuan memecahkan masalah siswa. Membiasakan bekerja ilmiah diharapkan dapat menumbuhkan kebiasaan berpikir dan bertindak yang merefleksikan penguasaan pengetahuan, kemampuan dan sikap ilmiah yang dimiliki siswa, sehingga dengan sendirinya model pembelajaran itu akan berakibat pada meningkatnya pengetahuan, kemampuan dan sikap ilmiah siswa sebagai hasil belajar.

Menurut Arends (2008) model pembelajaran berbasis masalah (problem based learning) merupakan model pembelajaran yang mengorganisasikan pembelajaran di sekitar pertanyaan dan masalah, melalui pengajuan situasi kehidupan nyata yang otentik dan bermakna, yang mendorong siswa untuk melakukan proses penyelidikan dan inkuri, dengan menghindari jawaban sederhana, serta memungkinkan adanya berbagai macam solusi dari situasi tersebut. Pembelajaran berdasarkan masalah keaktifan siswa lebih diutamakan karena kegiatan dalam pembelajaran berdasarkan masalah meliputi analisis terhadap masalah, merumuskan hipotesis, merencanakan penelitian sampai pelaksanannya.

Beberapa peneliti sebelumnya telah menunjukkan dampak positif dari pengaruh model pembelajaran berbasis masalah yaitu Zunanda, M., dan Karya Sinulingga (2015) menyatakaan bahwa keterampilan pemecahan masalah fisika siswa yang menggunakan model pembelajaran berbasis masalah lebih baik dibandingkan dengan pembelajaran konvensional, keterampilan pemecahan masalah fisika siswa dengan kemampuan berpikir kritis di atas rata-rata menunjukkan perbedaan dan hasil yang lebih baik dari pada siswa dengan kemampuan berpikir kritis di bawah rata-rata, serta terdapat interaksi antara model pembelajaran berbasis masalah dan kemampuan berpikir kritis dalam mempengaruhi keterampilan pemecahan masalah fisika siswa dan Manalu, Andriono (2016) dari hasil penelitian dapat disimpulkan bahwa penggunaan model problem based learning pada materi fluida statis secara signifikan dapat lebih efektif dalam meningkatkan kemampuan pemecahan masalah siswa dan berada pada kategori tinggi.

Penelitian sebelumnya telah membuktikan bahwa model pembelajaran PBL dapat meningkatkan kemampuan pemecahan masalah siswa. Berdasarkan uraian di atas, maka peneliti berkeinginan untuk melakukan penelitian dengan judul :"Pengaruh Model Problem Based Learning Terhadap Kemampuan Pemecahan Masalah Pada Materi Suhu Dan Kalor Di Kelas X Semester II SMA Negeri 5 Medan T.P. 2017/2018". 
Abu Bakar dan Maria Evlin Panjaitan ; Pengaruh Model Problem Based Learning Terhadap Kemampuan Pemecahan Masalah Pada Materi Suhu Dan Kalor Di Kelas X Semester II Sma Negeri 5 Medan

T.P. $2017 / 2018$

\section{METODE PENELITIAN}

Penelitian ini dilaksanakan di SMA N 5

Medan dengan populasi seluruh siswa kelas $\mathrm{X}$ MIPA semester II tahun ajaran 2017/2018 yang berjumlah 7 kelas. Sampel penelitian yaitu kelas $\mathrm{X}$ MIA-2 sebagai kelas eksperimen yang diberi perlakuan model pembelajaran PBL dan kelas X MIPA-5 sebagai kelas kontrol yang diberi perlakuan pembelajaran konvensional. masingmasing kelas memiliki siswa berjumlah 33 siswa. Teknik pengambilan sampel dilakukan dengan random sampling. Jenis penelitian ini ialah quasi eksperiment dengan two group pretest-postest design. Instrumen yang digunakan dalam penelitian adalah essay tes yang berjumlah 7 butir, lembar penilaian sikap dan lembar penilaiaan keterampilan. Pengaruh adanya model PBL dianalisis dengan uji kesamaan dua rata-rata (uji satu pihak).

\section{HASIL DAN PEMBAHASAN}

\section{a. Hasil Penelitian}

Penelitian ini merupakan penelitian eksperimen yang meelibatkan dua kelas yang diberi perlakuan yang berbeda yaitu kelas eksperimen diajarkan dengan model PBL dan kelas kontrol diajarkan dengan model pembelajaran konvensional. Sebelum kedua kelas diterapkan model yang berbeda maka terlebih dahulu diberikan pretes yang bertujuan untuk mengetahui kemampuan awal belajar siswa pada masing-masing kelas.

Hasil data pretes pada kelas eksperimen diperoleh nilai rata-rata 16,54 dan dan pada kelas kontrol diperoleh nilai rata-rata 16,45. Setelah itu kedua kelas diberi perlakuan. Kelas eksperimen diberi perlakuan dengan model PBL dan kelas kontrol diberi perlakuan dengan pembelajaran konvensional. Setelah diberi perlakuan kedua kelas diberikan postes. Hasil data postes pada kelas eksperimen diperoleh nilai rata-rata 78,31 dan pada kelas kontrol diperoleh nilai ratarata 73,85. Data pretes dan postes kelas eksperimen dan kelas kontrol ditunjukkan pada Gambar 1.

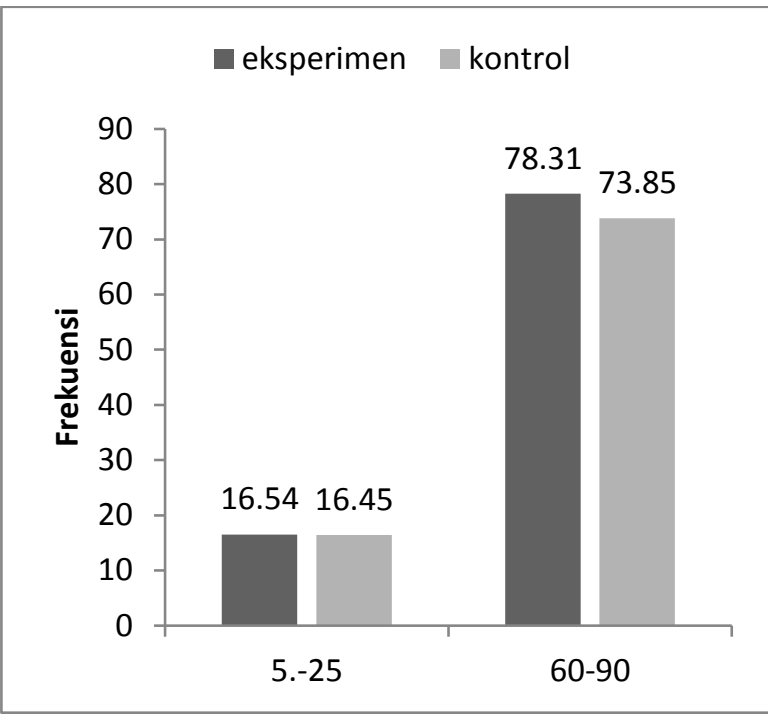

Gambar 1. Data pretes dan postes kelas eksperimen dan kelas control

Sebelum menganalisis uji hipotesis dilakukan uji prasyarat yaitu uji normalitas dan uji homogenitas. Uji normalitas dengan menggunakan uji lilliefors, data pretes diperoleh bahwa kedua sampel berdistribusi normal. Begitupun dengan data postes bahwa kedua sampel berdistribusi normal. Berikut tabel uji normalitas data pretes dan data postes kedua sampel.

Tabel 1. Uji normalitas data pretes dan data postes kedua sampel

\begin{tabular}{|l|c|c|c|c|c|}
\hline \multirow{2}{*}{ Kelas } & \multicolumn{2}{|c|}{ Pretes } & \multicolumn{2}{c|}{ Postes } & \multirow{2}{*}{ Hasil } \\
\cline { 2 - 5 } & Lhitung & Ltabel & Lhitung & Ltabel & \\
\hline $\begin{array}{l}\text { Ekspe- } \\
\text { rimen }\end{array}$ & 0,109 & 0,015 & 0,093 & 0,154 & Normal \\
\hline $\begin{array}{l}\text { Kon- } \\
\text { trol }\end{array}$ & 0,093 & 0,015 & 0,100 & 0,154 & Normal \\
\hline
\end{tabular}

Setelah kedua sampel berdistribusi normal, dilakukan uji homogenitas untuk mengetahui apakah kedua sampel berasal dari populasi yang homogen atau tidak. Berikut tabel hasil uji homogen data pretes dan data postes kedua sampel ditunjukkan pada Tabel 2. 
Tabel 2. Uji homogenitas data pretes dan data postes kedua sampel

\begin{tabular}{|c|c|c|c|}
\hline $\begin{array}{c}\text { piji } F \\
\text { Data }\end{array}$ & $F_{\text {hitung }}$ & $F_{\text {tabel }}$ & Kesimpulan \\
\hline Pretes & 1,1138 & 1,835 & Homogen \\
\hline Postes & 1,1297 & 1,835 & Homogen \\
\hline
\end{tabular}

Pengujian hipotesis dalam penelitian ini menggunakan uji kesamaan dua rata-rata (uji dua pihak) dan uji kesamaan dua rata-rata (uji satu pihak). Hasil uji hipotesis ditunjukkan pada Tabel 3.

Tabel 3. Uji hipotesis data pretes dan data postes kedua sampel

\begin{tabular}{|c|c|c|c|}
\hline $\begin{array}{c}\text { vij t } \\
\text { Data }\end{array}$ & thitung & tabel & Kesimpulan \\
\hline pretes & $\begin{array}{c}0,06 \\
21\end{array}$ & $\begin{array}{c}1,99 \\
9\end{array}$ & $\begin{array}{c}\text { Kemampuan } \\
\text { awal siswa } \\
\text { kedua sampel } \\
\text { sama }\end{array}$ \\
\hline postes & $\begin{array}{c}2,66 \\
74\end{array}$ & $\begin{array}{c}\text { Adanya } \\
87\end{array}$ & $\begin{array}{c}\text { perbedaan } \\
\text { yang } \\
\text { signifikan }\end{array}$ \\
\hline
\end{tabular}

Hasil uji hipotesis dengan menggunakan uji kesamaan dua rata-rata (uji satu pihak) dengan $\alpha=0,01$ diperoleh bahwa $t_{\text {hitung }}>t_{\text {tabel }}$ dengan demikian ada perbedaan yang signifikan dari model PBL terhadap kemampuan pemecahan di kelas X semester II SMA Negeri 5 T.P. 2017/2018.

Hasil observasi sikap belajar siswa di kelas eksperimen mengalami peningkatan tiap pertemuan dengan model pembelajaran PBL. Adapun aspek yang dinilai dalam penilaian keterampilan ini adalah menggunakan alat dan bahan, mengambil data, mengolah data, dan menyimpulkan. Penilaian Sikap belajar siswa ditunjukkan pada Tabel 4 .
Tabel 4. Sikap belajar siswa pada kelas eksperimen tiap pertemuan.

\begin{tabular}{|c|c|c|}
\hline Pertemuan & $\begin{array}{c}\text { Nilai rata- } \\
\text { rata }\end{array}$ & Kategori \\
\hline Pertemuan I & 82,39 & Baik \\
\hline Pertemuan II & 85,80 & Sangat baik \\
\hline $\begin{array}{c}\text { Pertemuan } \\
\text { III }\end{array}$ & 89,39 & Sangat baik \\
\hline
\end{tabular}

Berdasarkan tabel 4 untuk kelas eksperimen siswa pertemuan I yaitu 82,39 tergolong baik. Pertemuan II terjadi peningkatan menjadi 85,80 yaitu pada kategori sangat baik, pertemuan III meningkat lagi menjadi 89,39 dengan kategori sangat baik.

Data peningkatan sikap belajar siswa dengan menggunakan model pembelajaran PBL menunjukkan bahwa untuk kelas eksperimen dari pertemuan I sampai pertemuan III sikap belajar siswa mengalami peningkatan. Hal ini sikap siswa memiliki pengaruh yang positif terhadap kemampuan pemecahan masalah siswa.

Hasil observasi keterampilan belajar siswa di kelas eksperimen mengalami peningkatan tiap pertemuan dengan model pembelajaran PBL. Penilaian keterampilan belajar siswa ditunjukkan pada Tabel 5 berikut.

Tabel 5. Keterampilan belajar siswa pada kelas eksperimen tiap pertemuan

\begin{tabular}{|c|c|c|}
\hline Pertemuan & $\begin{array}{c}\text { Nilai rata- } \\
\text { rata }\end{array}$ & Kategori \\
\hline Pertemuan I & 79,80 & Baik \\
\hline Pertemuan II & 82,07 & Baik \\
\hline $\begin{array}{c}\text { Pertemuan } \\
\text { III }\end{array}$ & 83,33 & Baik \\
\hline
\end{tabular}

Berdasarkan tabel 5 untuk kelas eksperimen siswa pertemuan I yaitu 79,80 tergolong baik. Pertemuan II terjadi peningkatan menjadi 82,07 yaitu pada kategori baik, pertemuan III meningkat lagi menjadi 83,33 dengan kategori baik.

Data peningkatan eksperimen belajar siswa dengan menggunakan model pembelajaran PBL menunjukkan bahwa untuk kelas eksperimen dari pertemuan I sampai pertemuan III sikap belajar siswa mengalami peningkatan, 
Abu Bakar dan Maria Evlin Panjaitan ; Pengaruh Model Problem Based Learning Terhadap Kemampuan Pemecahan Masalah Pada Materi Suhu Dan Kalor Di Kelas X Semester II Sma Negeri 5 Medan

T.P. 2017/2018

walaupun masih dalam kategori yang sama yaitu baik hal ini menunjukkan bahwa ada pengaruh penggunaan model PBL terhadap keterampilan siswa selama proses pembelajaran.

\section{b. Pembahasan}

Model PBL dapat meningkatkan kemampuan pemecahan masalah siswa, sikap serta keterampilan siswa. Adanya peningkatan pengetahuan kemampuan pemecahan masalah siswa disebabkan oleh kelebihan model PBL. Runtutan kegiatan siswa tersebut menjadi pengalaman pribadinya yang memiliki kesan tersendiri. Pengetahuan yang diperoleh siswa secara langsung akan lebih mudah diingat dibandingkan pengetahuan yang diberikan oleh guru, dari pengalamannya siswa telah membangun konsep pribadi (selft-concept) dalam pemikirannya. Jadi pada saat siswa menghadapi permasalahan serupa/identik baik dalam pembelajaran seperti menjawab soal-soal maupun dalam kehidupannya sehari-hari, ia dapat menggunakan konsep tersebut dalam menyelesaikan masalah. Keberhasilan siswa dalam menyelesaikan masalah berdampak positif terhadap kemampuan pemecahan masalahnya.

Pembelajaran dimulai dengan fase pertama peneliti menjelaskan tujuan pembelajaran secara umum dan memotivasi siswa untuk terlibat aktif dalam pemecahan masalah. Langkah kedua peneliti membantu siswa untuk memdefinisikan dan mengorganisasikan tugas belajar sesuai LKS. Tahap ketiga peneliti mendorong siswa untuk mendapatkan informasi yang tepat dari hasil percobaan dalam pemecahan masalah. Pada langkah keempat peneliti mengajak siswa untuk bertukar pikiran antar kelompok melalui presentasi diiringi tanya jawab. Pada fase kelima peneliti beserta siswa melakukan refleksi terhadap investigasi dan proses yang dilalui siswa dalam memecahkan masalah sesuai LKS.

Selama proses pembelajaran peneliti juga menilai sikap dan keterampilan siswa dimana ketika diberlakukannya model PBL terlihat juga perubahan sikap siswa menjadi lebih baik lagi sikap yang dinilai yaitu rasa ingin tahu, sopan santun, bertanggung jawab, teliti, bekerja sama dan menghargai dan yang tinggi persentasenya selama dari pertemuan I sampai pertemuan III yaitu tanggung jawab yaitu $63,6 \%$ dan yang paling rendah itu adalah kejujuran yaitu 57, 6\%. Kelas eksperimen terlihat siswa ketika dibagi tugas dan guru mengarahkan siswa untuk mengerjakan sesuai instruksi guru mereka sangat bertanggung jawab dan mengerjakannya serta mengumpulkan tugas tepat waktu namun, ketika guru meninjau pekerjaan mereka lagi tidak semua jujur dalam mengerjakan tugasnya dan untuk keterampilan siswa selama pembelajaran, model PBL juga membantu meningkatkan keterampilan siswa. Keterampilan yang dinilai adalah menggunakan alat dan bahan, mengambil data, mengolah data, dan menyimpulkan, dari keempatnya deskriptor yang paling tinggi persentasenya yaitu deskriptor kedisiplinan 55\% dan yang paling rendah itu adalah berpikir kreatif yaitu $18 \%$ bahwa siswa mulai mendengarkan guru dan disiplin dalam mengerjakan praktikum namun kurang kreatif dalam menciptakan atau menghasilkan kreatifitas baru.

Hasil penelitian terdahulu juga menunjukkan adanya peningkatan kemampuan pemecahan masalah siswa yaitu Simamora dan Victorya (2016) berdasarkan hasil penelitian yang diperoleh dari hasil analisa data dan pengujian hipotesis maka diperoleh bahwa ada pengaruh model pembelajaran berbasis masalah terhadap hasil belajar siswa pada materi suhu dan kalor. Hasil belajar secara signifikan berbeda hasil antara sampel yang menggunakan pembelajaran konvensional dengan hasil belajar dengan menggunakan model pembelajaran berbasis masalah. Aktivitas belajar siswa di kelas eksperimen dengan menggunakan model pembelajaran berbasis masalah yang diperoleh setiap pertemuan dinyatakan meningkat dalam kategori baik. Begitu pula setelah dilakukan observasi psikomotorik siswa kelas eksperimen selama empat kali pertemuan, perkembangan psikomotorik siswa mengalami peningkatan. Terdapat peneliti lain yaitu Sitika, Muhardjito, dan Markus (2015) memaparkan hasil penelitiannya, bahwa pengaruh kemampuan pemecahan masalah fisika siswa yang belajar dengan model PBL berbasis GI lebih tinggi dan juga terdapat interaksi antara model PBL berbasis GI dan kerja ilmiah siswa terhadap kemampuan 
pemecahan masalah fisika, serta kemampuan pemecahan masalah fisika menjadi lebih baik/tinggi pada siswa yang memiliki kerja ilmiah tinggi dan belajar dengan model PBL berbasis GI, begitu pula sebaliknya.

$$
\text { Penggunaan model pembelajaran }
$$
berbasis masalah dapat meningkatkan kemampuan pemecahan masalah siswa, namun masih ada kendala yang dihadapi peneliti selama penelitian. Kendala yang dihadapi selama penelitian terdapat pada fase kedua dan ketiga yaitu mengorganisasikan siswa untuk meneliti dan membantu investigasi mandiri dan kelompok siswa didalam fase ini siswa masih banyak kesulitan dalam melakukan investigasi mandiri dan peneliti kesusahan dalam mengorganisasikan siswa untuk meneliti hal ini terlihat melalui pada saat siswa diorganisasikan untuk meneliti dan melakukan investigasi mandiri siswa banyak yang tidak melakukan percobaan dan tidak disiplin selama praktikum dan tidak bertanggung jawab terhadap kelompoknya masing-masing melainkan menggangu kelompok lain yang sedang praktikum hal ini disebabkan oleh kurang kondusifnya kelas dan terlalu banyak jumlah siswa dalam satu kelompok sehingga siswa tidak bekerja sama dalam kelompok sehingga sebagian siswa pasif dalam kelompok tersebut. Cara mengatasi kendala diatas peneliti selanjutnya diharapkan dapat mengkondusikan kelas dengan baik sehingga tidak terjadi keributan dalam pembelajaran, pembagian kelompok sebaiknya siswa 4-5 orang dalam satu kelompok.

Hasil pengamatan selama melaksanakan penelitian, tampak bahwa semangat dan pengetahuan konseptual siswa yang diajar dengan model PBL lebih baik jika dibandingkan dengan siswa yang diajar dengan menggunakan model pembelajaran konvensional.

\section{KESIMPULAN DAN SARAN \\ a. Kesimpulan \\ Berdasarkan hasil penelitian, peneliti mengambil simpulan bahwa ada pengaruh yang signifikan dari model problem based learning}

terhadap kemampuan pemecahan masalah pada materi suhu dan kalor di kelas X Semester II SMA Negeri 5 Medan T.P. 2017/2018.

\section{b. Saran}

Berdasarkan hasil penelitian, maka peneliti mempunyai beberapa saran, yaitu:

1. Model PBL dapat menjadi alternatif dalam pembelajaran fisika.

2. Guru sebaiknya memperhatikan efisiensi waktu sebaik mungkin dalam menerapkan model pembelajaran Problem Based Learning agar tujuan pembelajaran dapat dicapai serta butuh persiapan yang baik dalam melaksanakan model ini sebelum masuk ke kelas.

\section{DAFTAR PUSTAKA}

Arends, R. I. 2008. Learning to Teach (Terjemahan Belajar untuk Mengajar). Yogyakata: Pustaka Pelajar.

Hamalik, O. 2003. Proses Belajar Mengajar. Jakarta: Bumi Aksara.

Manalu, Andriono. 2016. Efek Model Problem Based Learning Terhadap Kemampuan Pemecahan Masalah Siswa SMA Negeri 2 Pematang Siantar. Jurnal Inpafi. 4(2), 9198.

Simamora, P., dan Victorya, R. 2016. Penerapan Model Pembelajaran Berbasis Masalah pada Materi Suhu dan Kalor. Jurnal Pendidikan Indonesia. 5(2), 64-68.

Sitika, L. M., Muhardjito, dan Markus, D. 2015. Terhadap Kemampuan Pemecahan Masalah Fisika Ditinjau dari Kerja Ilmiah Siswa. Jurnal Universitas Negeri Malang. 6(1), 395-398.

Suyanto dan Jihad. 2013. Menjadi Guru Profesional, Strategi Meningkatkan Kualifikasi dan Kualitas Guru di Era Global. Jakarta: Esensi Erlangga Group. 
Abu Bakar dan Maria Evlin Panjaitan ; Pengaruh Model Problem Based Learning Terhadap Kemampuan Pemecahan Masalah Pada Materi Suhu Dan Kalor Di Kelas X Semester II Sma Negeri 5 Medan

T.P. $2017 / 2018$

Trianto. 2010. Mendesain Model Pembelajaran Inovatif-Progresif. Jakarta: Kencana.

Zunanda, M., dan Karya Sinulingga. 2015. Pengaruh Model Pembelajaran Berbasis Masalah dan Kemampuan Berpikir Kritis Terhadap Keterampilan Pemecahan Masalah Fisika Siswa SMK. Jurnal Pendidikan Fisika. 4(1), 63-70.

Trianto. 2010. Mendesain Model Pembelajaran Inovatif-Progresif. Jakarta: Kencana.

Suyanto dan Jihad. 2013. Menjadi Guru Profesional, Strategi Meningkatkan Kualifikasi dan Kualitas Guru di Era Global. Jakarta: Esensi Erlangga Group. 